\title{
Separasi dan Reattachment Aliran di Belakang Gundukan (Bump) Setengah Lingkaran, Segitiga dan Persegi Panjang
}

\author{
Setyo Hariyadi S.P. 1 \\ Setiyo 1 \\ Supriadi 2
}

Politeknik Penerbangan Surabaya

1) Program Studi Teknik Pesawat Udara, Politeknik Penerbangan Surabaya

2) Program Studi Teknik Bangunan dan Landasan, Politeknik Penerbangan Surabaya

Jl Jemur Andayani I/73, Wonocolo, Surabaya 60236

Email: hudzaifahsetyo@gmail.com

\begin{abstract}
Characteristic of viscous flow through a contour always become the interesting topic to be studied. This research studied characteristic of turbulent viscous flow through a flat plate mounted by bump. Target of this research is to know the flow characteristic through the semicircle, triangle and quadrangular bump, and also to get distribution coefficient of pressure $\left(C_{p}\right)$, separation point, coefficient of pressure drag $\left(C_{D p}\right)$ and coefficient of total drag $\left(C_{D}\right)$. Beside that, in this research also conduct smoke visualization to know visualization of turbulent viscous flow through a flat plate mounted by bump. This experiment is conducted in subsonic wind tunnel. Form of the bump that is used are semicircle, triangle and quadrangular, and free stream velocity equal to $9.75 \mathrm{~m} / \mathrm{s}$ and $15.5 \mathrm{~m} / \mathrm{s}$. Pressure coefficient got from static pressure measurement over flat plate and bump by using wall pressure tap. Coefficient of pressure drag $\left(C_{D p}\right)$ got from calculation based pressure. The measurement of velocity profile over flat plate and bump by using pitot tube. Measurement conducted at 6 point before side of upstream bump, 1 point at top bump and 13 point after side of downstream bump where distance between the points are $20 \mathrm{~mm}$. While for the direction of vertical, the measurement taken at 80 point started from height $80 \mathrm{~mm}$ from surface until near the surface. Existence of bump on flat plate result the flow becomes separation so that generate the total drag force addition over flat plate. The highest total drag force occured on flat plate with triangle bump, then on flat plate with quadrangular bump and the smallest occur on flat plate with semicircle bump.
\end{abstract}

Keywords: Bump, pressure coefficient $\left(C_{p}\right)$, pressure drag coefficient $\left(C_{D p}\right)$, total drag coefficient $\left(C_{D}\right)$, speed profile, separation point.

\section{PENDAHULUAN}

Kemajuan ilmu manusia saat ini terutama dalam bidang mekanika fluida mendorong manusia untuk meneliti aliran fluida yang melintasi suatu benda. Hal ini terjadi karena pada kehidupan sehari-hari manusia tidak terlepas dari aliran fluida, misalnya angin yang melintasi suatu gedung atau bangunan dengan bentuk tertentu. Penelitian-penelitian tentang aliran fluida yang dilakukan bertujuan untuk mengetahui karakteristik aliran fluida pada saat melintasi suatu benda.

Pada aliran fluida nyata selalu menunjukkan adanya suatu daerah yang alirannya terhambat, yaitu daerah di dekat permukaan yang kecepatan relatif terhadap permukaan bervariasi antara nol hingga $99 \%$ kecepatan freestream. Daerah yang terhambat ini disebut lapisan batas (boundary layer). Konsep lapisan batas ini pertama kali diperkenalkan oleh Ludwig Prandtl dalam tahun 1904. Efek-efek viskositas akan terkonsentrasi dalam lapisan batas ini (viscous region) sedangkan di luar lapisan batas efek viskositas dapat diabaikan (nonviscous region). 


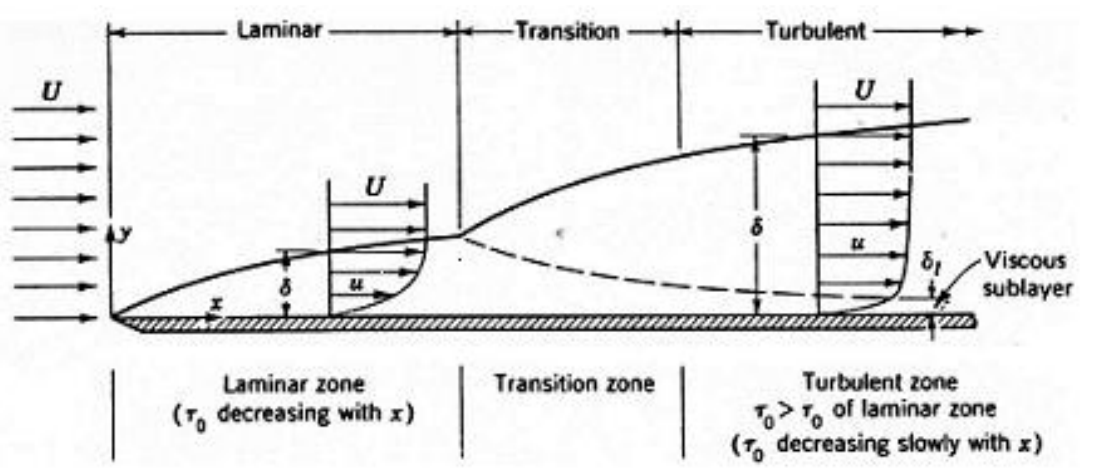

Gambar 1. Lapisan batas laminer dan turbulen sepanjang pelat datar.

Proses pembentukan lapisan batas dapat dilihat pada gambar 1. Ketika aliran melintasi pelat datar, pada bagian depan partikel-partikel fluida yang cukup dekat terhadap pelat dihambat oleh adanya tegangan geser yang besar. Lapisan batas menebal dalam arah yang sama dengan arah aliran. Pada lapisan batas ini terjadi perubahan kecepatan darinol di permukaan pelat hingga kecepatan mendekati $U$ pada jarak $\delta$.

Lapisan batas dapat dibedakan menjadi dua bagian yaitu lapisan batas laminer dan lapisan batas turbulen yang tergantung pada besarnya harga bilangan Reynolds. Di dalam aliran fluida proses peralihan dari aliran laminer ke turbulen disebut sebagai keadaan transisi. Faktor yang mempengaruhi lamanya proses transisi adalah gradien tekanan, kekasaran permukaan, gaya bodi dan gangguan aliran bebas. Begitu lapisan batas mulai menebal, ketidakstabilan pun terjadi dan mengakibatkan percampuran partikel (gerak acak) dan perubahan momentum dalam fluida hingga menyebabkan terbentuknya lapisan batas turbulen. Pada lapisan batas turbulen, profil kecepatan yang terbentuk lebih tebal (bundar) dengan gradien kecepatan di permukaan plat dan tegangan gesernya lebih tinggi daripada kondisi laminar maupun transisi.

Keberadaan pressure gradient di sepanjang permukaan benda padat mempunyai pengaruh yang sangat besar dan signifikan terhadap pertumbuhan boundary layer. Seperti aliran yang melintasi suatu silinder bulat (gambar 2). Gambar 2 menunjukkan pertumbuhan boundary layer pada permukaan silinder bulat yang mana pertumbuhannya lebih banyak dipengaruhi oleh adanya pressure gradient akibat bentuk silinder. Pada gambar tersebut tiap titik digambarkan dengan sumbu $\mathrm{x}$ searah kecepatan tangensial dan sumbu y yang tegak lurus sumbu x. Dimana U adalah kecepatan fluida ideal diluar boundary layer.

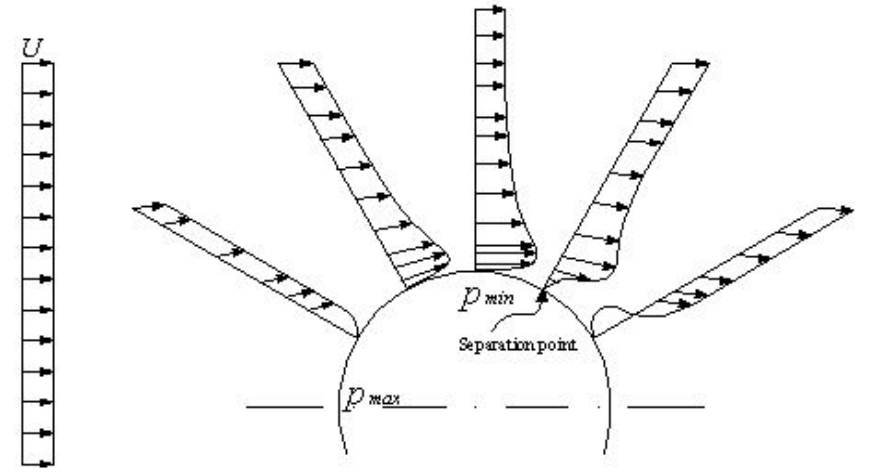

Gambar 2. Pertumbuhan boundary layer pada silinder bulat

Aliran viscous yang melewati bump berbentuk segitiga akan mengalami penurunan tekanan di sisi upstream dan kenaikan tekanan di sisi downstream. Saat momentum aliran fluida tidak dapat melawan kenaikan tekanan dan gesekan dengan permukaan maka aliran fluida akan terseparasi. Titik dimana mulai terjadi gejala separasi disebut titik separasi. Daerah setelah titik separasi mempunyai tekanan yang lebih kecil daripada daerah di sisi upstream sehingga mengakibatkan perbedaan tekanan yang besar. Akibat perbedaan tekanan ini maka akan terjadi gaya drag pada benda. 
Kecepatan aliran fluida akan mencapai harga nol atau stagnasi di depan silinder, dan seiring dengan pergerakan aliran, kecepatannya akan bertambah besar sehingga mencapai harga maksimum pada bagian atas dari silinder. Setelah mencapai harga maksimum, kecepatan fluida akan berangsur-angsur menurun saat fluida menuju ke daerah buritan (aftedge).

Seiring dengan kecepatan aliran fluida, tekanan pada permukaan benda padat juga akan mengalami perubahan yaitu berharga maksimum pada daerah depan dan berharga minimum pada daerah diatas silinder. Seperti yang ditunjukkan gambar 2 boundary layer mulai terjadi pada titik stagnasi depan, kemudian seiring dengan pergerakan aliran fluida, boundary layer mengalami pertumbuhan dimana ketebalannya akan semakin bertambah.

Pada saat bergerak ke bagian atas dari silinder, aliran fluida akan mengalami penurunan tekanan, atau pressure gradient lebih kecil dari nol $(d p / d x<0)$ dan disebut favourable pressure gradient. Dengan adanya favourable pressure gradient ini aliran fluida yang dekat dengan permukaan bergerak perlahan, dan terjadi kenaikan kecepatan.

Saat aliran fluida mencapai puncak silinder dan mulai bergerak turun ke daerah belakang silinder, aliran fluida akan mengalami kenaikan tekanan. Tekanan ini akan terus naik dan mencapai harga maksimum tepat pada titik separasi dan kemudian tekanannya konstan. Pressure gradient yang terjadi mulai dari puncak silinder ke daerah belakang silinder, harganya lebih besar dari nol $(d p / d x>0)$ dan disebut adverse pressure gradient. Pada suatu titik dimana aliran tidak sanggup lagi mengatasi adverse pressure gradient bersama-sama dengan tegangan geser, maka pada saat itu aliran fluida di dalam boundary layer akan mengalami separasi dan titik tersebut dinamakan titik separasi. Di belakang titik separasi, terdapat sebagian fluida yang mengalami aliran balik, dan aliran fluida tidak mengikuti lagi bentuk dari solid body. Aliran fluida mulai tidak stabil dan terjadi pergolakan aliran. Daerah dimana terjadi pergolakan aliran disebut wake.

Telah banyak penelitian yang berkaitan dengan pengontrolan boundary layer. Penelitian yang dilakukan Andi Joko (2001) mengenai pengaruh lokasi permukaan kasar sebagai inlet disturbance terhadap karakteristik boundary layer dan gejala separasi pada pelat melengkung didapatkan bahwa semakin besar jarak permukaan kasar terhadap pelat melengkung maka tingkat turbulensi aliran yang dibangkitkan lebih besar sehingga aliran mempunyai ketahanan yang lebih terhadap terjadinya separasi. Penelitian yang dilakukan Fatchan Nurul (2000) mengenai pengaruh inlet disturbance terhadap karakteristik boundary layer dan gejala separasi pada pelat melengkung didapatkan bahwa semakin besar kekasaran inlet disturbance maka tingkat turbulensi aliran yang dibangkitkan lebih besar sehingga aliran mempunyai ketahanan yang lebih terhadap terjadinya separasi. Dari kedua penelitian tersebut juga didapatkan bahwa semakin besar sudut kelengkungan pelat maka separasi akan terjadi lebih awal.

Penelitian tentang pengontrolan boundary layer lainnya dilakukan oleh Ari Susanto (2004) mengenai karakteristik turbulent boundary layer di sekitar alur berbentuk V tunggal yang melintang pada pelat datar. Dari penelitian tersebut didapatkan bahwa akibat adanya alur menyebabkan terjadinya kenaikan total drag serta timbul vortex quasi stabil dalam a lur. Selain itu adanya alur mengakibatkan profil kecepatan turbulen yang terjadi relatif konstan dibandingkan dengan profil kecepatan turbulen yang terjadi pada pelat datar halus. Penelitian yang dilakukan M. Nuch (2004) mengenai karakteristik turbulent boundary layer setelah single square groove pada pelat datar didapatkan bahwa terjadi penurunan $C_{f}$ total di daerah setelah alur dibandingkan dengan $C_{f}$ total pada pelat datar halus. Berdasarkan penelitian-penelitian tersebut, maka muncul pemikiran untuk melakukan penelitian tentang aliran melewati bump berbentuk segitiga, setengah lingkaran dan segi empat tanpa diberi inlet disturbance dengan variasi 2 bilangan Reynolds.

\section{METODE}

Tujuan dari penelitian ini adalah untuk mengetahui karakteristik aliran melintasi bump berbentuk segitiga meliputi distribusi koefisien tekanan $\left(C_{p}\right)$ sepanjang pelat datar dan bump, profil kecepatan sebelum, sesudah dan di atas bump, titik separasi, perhitungan koefisien pressure drag $\left(C_{D p}\right)$ pada bump berdasarkan tekanan, perhitungan koefisien total drag $\left(C_{D}\right)$ sepanjang pelat datar berdasarkan perubahan momentum kecepatan sebelum dan sesudah melewati bump. Penelitian ini juga bertujuan untuk mendapat gambaran aliran yang melewati bump dengan visualisasi menggunakan asap. Variasi bilangan Reynolds 
yang digunakan yaitu terkait dengan kecepatan freestream $9,75 \mathrm{~m} / \mathrm{s}$ dan $15,5 \mathrm{~m} / \mathrm{s}$. Benda kerja yang digunakan adalah pelat datar yang terdapat gundukan ( segi empat sedangkan detail dari gambar penelitian dapat dilihat pada gambar 3 dan 4 .

Wall pressure tube terpasang pada permukaan pelat datar dan bump yang digunakan untuk mengukur tekanan statis aliran fluida. Sedangkan total pressure tube digunakan untuk mengukur tekanan stagnasi aliran fluida. Dari kedua tekanan tersebut dengan menggunakan persamaan Bernoulli dapat diperoleh tekanan dinamis aliran fluida. Manometer berfungsi untuk menyatakan besar tekanan yang diukur oleh wall pressure tube dan total pressure tube. Manometer yang digunakan ini mempunyai kemiringan sebesar $30^{\circ}$ dengan maksud untuk mempermudah pembacaan $\Delta \mathrm{h}$ terukur. Wind tunnel digunakan sebagai tempat pengujian benda uji. Alat ini mempunyai test section berbentuk persegi panjang dengan panjang $45 \mathrm{~cm}$, tinggi $30 \mathrm{~cm}$ dam lebar $30 \mathrm{~cm}$. Kecepatan maksimumnya $20 \mathrm{~m} / \mathrm{s}$ dan intensitas turbulensi sebesar $0.6 \%$.

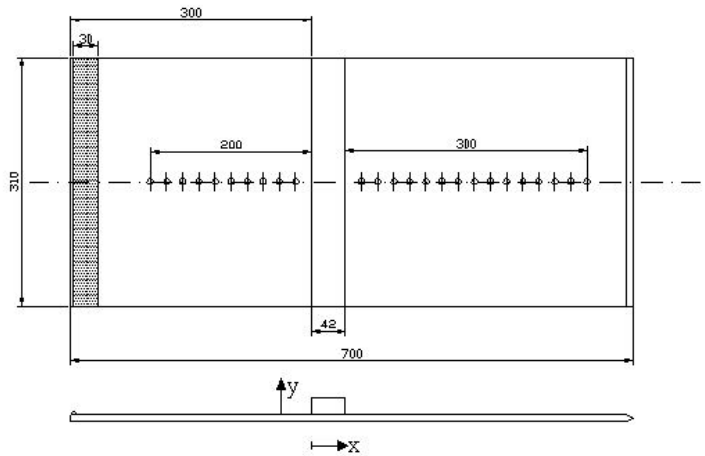

Gambar 3. Model bump

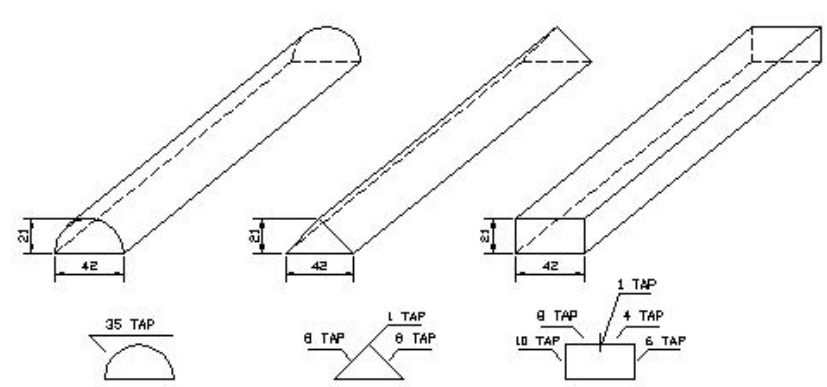

Gambar 4. Bump Setengah Lingkaran, Segitiga dan Segi Empat

\section{HASIL DAN PEMBAHASAN \\ Harga Koefis ien Pressure Drag $\left(C_{D p}\right)$}

Pada tabel 1 dapat dilihat bahwa harga gaya drag pada sisi upstream bump setengah lingkaran lebih kecil dibandingkan dengan bump segitiga baik untuk $R e=21000$ ataupun $R e=13000$. Hal ini dikarenakan pada bump setengah lingkaran mempunyai sudut antara garis normal permukaan bump dengan arah aliran berubah dari $0^{\circ}$ pada awal bump menjadi $90^{\circ}$ pada puncak bump, sedangkan pada bump segitiga mempunyai sudut antara garis normal permukaan bump dengan arah aliran yang tetap yaitu sebesar $45^{\circ}$. Hal tersebut menyebabkan streamtube aliran yang terbentuk di bagian upstream bump setengah lingkaran lebih kecil dibandingkan bump segitiga sehingga kecepatan aliran yang melewati upstream bump setengah lingkaran lebih besar daripada yang melewati upstream bump segitiga. Kecepatan yang lebih besar pada bump setengah lingkaran berarti distribusi tekanan statis bump setengah lingkaran lebih kecil daripada bump segitiga (gambar 5(a) dan gambar 5(b)) atau dengan kata lain aliran yang melalui bump segitiga menjadi lebih terhambat dibandingkan pada bump setengah lingkaran. Gaya drag pada sisi upstream bump segitiga lebih kecil dibandingkan dengan bump persegi panjang baik untuk $R e=21000$ ataupun $R e=13000$. Hal ini dikarenakan pada bump segitiga mempunyai sudut antara garis normal permukaan bump dengan arah aliran yang tetap yaitu sebesar $45^{\circ}$, sedangkan pada bump persegi panjang mempunyai sudut antara garis normal permukaan bump dengan arah aliran yang tetap yaitu sebesar $90^{\circ}$. Hal tersebut menyebabkan streamtube aliran yang terbentuk di bagian upstream bump segitiga lebih kecil dibandingkan bump persegi panjang sehingga kecepatan aliran yang melewati upstream bump segitiga lebih besar daripada yang melewati upstream bump persegi panjang. Kecepatan yang lebih besar pada bump segitiga berarti distribusi tekanan statis bump segitiga lebih rendah daripada bump persegi panjang (gambar 5(a) dan gambar 5(b) ) atau dengan kata lain aliran yang melalui bump persegi panjang menjadi lebih terhambat dibandingkan pada bump segitiga.

Tabel 1. Koefisien pressure drag (CDp) pada bump 


\begin{tabular}{|c|c|c|c|c|c|}
\hline & \multirow{3}{*}{ BUMP } & \multirow{3}{*}{$\begin{array}{c}\text { Upstream } \\
F_{D U} L \\
\mathbf{N} / \mathbf{m}\end{array}$} & \multirow{3}{*}{$\begin{array}{c}\text { Downstream } \\
F_{D D} L \\
\mathrm{~N} / \mathrm{m}\end{array}$} & \multicolumn{2}{|c|}{ Pressure Drag } \\
\hline & & & & \multirow{2}{*}{$\frac{F_{D p} L}{\mathbf{N} / \mathbf{m}}$} & \multirow{2}{*}{$C_{D p}$} \\
\hline & & & & & \\
\hline \multirow{3}{*}{$\operatorname{Re}=21000$} & Setengah Lingkaran & -4.791 & -7.121 & 2.330 & 0.793 \\
\hline & Segitiga & -2.645 & -6.553 & 3.908 & 1.330 \\
\hline & Persegi Panjang & -2.403 & -7.021 & 4.618 & 1.571 \\
\hline \multirow{3}{*}{$\operatorname{Re}=13000$} & Setengah Lingkaran & -1.721 & -2.817 & 1.096 & 0.942 \\
\hline & Segitiga & -1.003 & -2.383 & 1.379 & 1.186 \\
\hline & Persegi Panjang & -0.973 & -2.728 & 1.755 & 1.509 \\
\hline
\end{tabular}

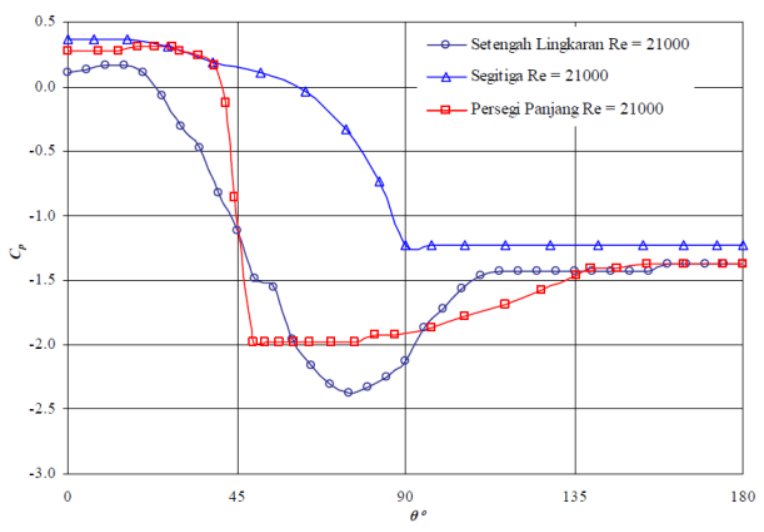

Gambar 5(a) Grafik Cp fungsi $\theta$ untuk $\mathrm{Re}=21000$

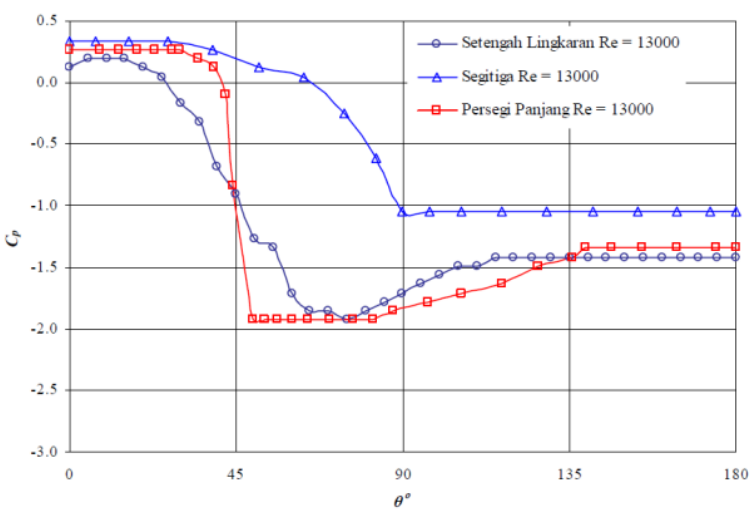

Gambar 5(b) Grafik $C p$ fungsi $\theta$ untuk $R e=13000$

Daerah separasi banyak berperan pada sisi downstream bump sehingga pada sisi downstream distribusi tekanan di daerah separasi mempunyai nilai terbesar. Sehingga untuk membandingkan besar gaya drag yang bekerja pada masing-masing sisi downstream bump cukup dengan membandingkan harga tekanan statis pada daerah separasi. Dari gambar 5(a) dan gambar 5(b) menunjukkan bahwa distribusi tekanan pada bump setengah lingkaran lebih kecil dibandingkan pada bump persegi panjang untuk $R e=$ 21000 ataupun $R e=13000$, hal ini berarti gaya drag pada sisi downstream bump setengah lingkaran lebih kecil dibandingkan dengan bump persegi panjang untuk kedua harga Re. Dari gambar 5(a) dan gambar 5(b) menunjukkan bahwa distribusi tekanan pada bump persegi panjang lebih kecil dibandingkan pada bump segitiga untuk $R e=21000$ ataupun $R e=13000$, hal ini berarti gaya drag pada sisi downstream bump persegi panjang lebih kecil dibandingkan dengan bump segitiga untuk kedua harga $R e$.

Gaya pressure drag (FDp) merupakan resultan dari gaya drag yang bekerja pada sisi upstream bump dengan gaya drag yang bekerja pada permukaan sisi downstream bump. Pada tabel 1 dapat dilihat bahwa gaya pressure drag (FDp) yang bekerja pada bump segitiga lebih kecil dibandingkan pada bump persegi panjang untuk $R e=21000$ maupun $R e=13000$. Hal ini disebabkan gaya drag yang bekerja pada sisi upstream bump segitiga lebih kecil daripada bump persegi panjang dan gaya drag yang bekerja pada sisi downstream bump segitiga lebih besar daripada bump persegi panjang. Sehingga, resultan gaya drag yang bekerja pada bump segitiga lebih kecil dibandingkan pada bump persegi panjang. Akibat gaya pressure drag yang kecil maka koefisien pressure drag $(C D p)$ menjadi kecil. Sedangkan gaya pressure drag untuk bump setengah lingkaran adalah yang terkecil dibandingkan pada bump segitiga dan persegi panjang. Hal ini dikarenakan pada sisi downstrean bump setengah lingkaran terdapat tekanan statis permukaan bump yang lebih besar dibandingkan pada sisi upstream bump untuk $R e=21000$ maupun $R e=13000$ (lihat gambar 5(a) dan gambar 5(b)). Akibat adanya beberapa tekanan pada sisi downstream yang lebih besar daripada sisi upstream, maka mengurangi resultan gaya pressure drag yang bekerja pada bump setengah lingkaran. Hal tersebut tidak tejadi pada bump segitiga dan persegi panjang sehingga gaya pressure drag pada bump setengah lingkaran adalah yang terkecil. 


\section{Harga Koefisien Total Drag $\left(C_{D}\right)$}

Harga koefisien total drag (CD) dihitung dengan menggunakan perubahan momentum aliran sebelum melewati bump dengan momentum aliran setelah melewati bump. Control volume yang digunakan pada penelitian ini dapat dilihat pada gambar 6 .

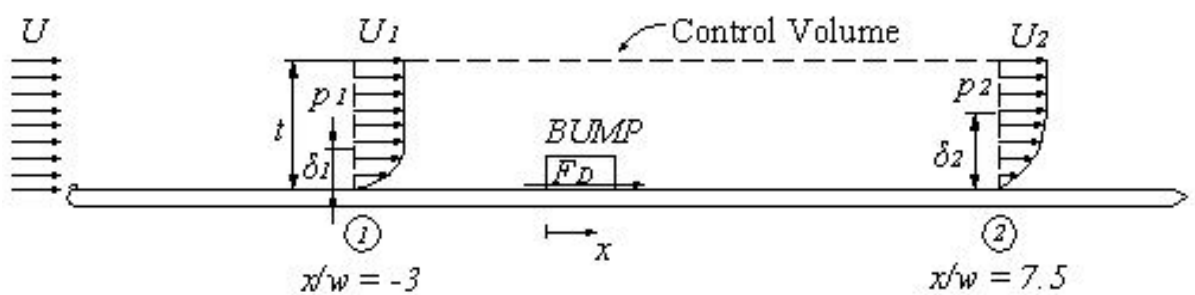

Gambar 4.6. Control volume persamaan momentum

Gambar 4.13 menunjukkan kontrol volume yang digunakan untuk mendapatkan persamaan momentum. Titik $x / w=0$ terletak pada awal bump. Titik 1 merupakan inlet aliran yang terletak pada $x / w$ $=-3$ dan titik 2 merupakan outlet aliran yang terletak pada $x / w=7.5$. U1 dan $U 2$ merupakan kecepatan freestream pada masing-masing titik, $P 1$ dan $P 2$ merupakan tekanan statis pada masingmasing titik, $\delta 1$ dan $\delta 2$ merupakan tebal boundary layer pada masing-masing titik, $t$ merupakan tebal daerah pengukuran ke arah $y$ dan $F D$ adalah gaya hambat yang terjadi mulai dari titik 1 sampai titik 2 .

Dari hasil penelitian serta proses perhitungan yang telah dilakukan didapatkan harga koefisien total drag $\left(C_{D}\right)$ yang terjadi di atas permukaan pelat datar baik untuk pe lat datar dengan bump setengah lingkaran, segitiga maupun persegi panjang. Koefisien drag yang terjadi sepanjang pelat datar merupakan gabungan dari koefisien gesek $\left(C_{f}\right)$ yang terjadi sepanjang permukaan dan koefisien pressure drag $\left(C_{D p}\right)$ yang terjadi akibat adanya bump. Adapun hasil tersebut dapat dilihat pada tabel 4.2.

Tabel 4.2 Koefisien total drag $\left(C_{D}\right)$ pada pelat datar

\begin{tabular}{|c|c|c|c|c|}
\hline \multicolumn{2}{|c|}{ BUMP } & $C_{D}$ & $C_{D p}$ & $C_{f}$ \\
\hline \multirow{3}{*}{$R e=21000$} & Setengah Lingkaran & 0.986 & 0.793 & 0.193 \\
\cline { 2 - 5 } & Segitiga & 3.022 & 1.330 & 1.692 \\
\cline { 2 - 5 } & Persegi Panjang & 1.678 & 1.571 & 0.107 \\
\hline \multirow{3}{*}{$R e=13000$} & Setengah Lingkaran & 1.136 & 0.942 & 0.193 \\
\cline { 2 - 5 } & Segitiga & 3.057 & 1.186 & 1.870 \\
\cline { 2 - 5 } & Persegi Panjang & 1.598 & 1.509 & 0.089 \\
\hline
\end{tabular}

Tabel 4.2 menunjukkan harga koefisien total drag $\left(C_{D}\right)$ pada masingmasing bump yang dihitung berdasarkan perubahan momentum dan tekanan statis aliran sebelum melewati bump dengan sesudah daerah separasi. Dari tabel 4.2 diketahui bahwa harga koefisien total drag $\left(C_{D}\right)$ bump setengah lingkaran lebih kecil daripada bump persegi panjang, hal ini dikarenakan aliran yang melewati bump persegi panjang lebih terseparasi daripada aliran yang melewati bump setengah lingkaran sehingga penurunan momentum dan tekanan statis aliran yang melewati bump persegi panjang lebih besar daripada aliran yang melewati bump setengah lingkaran. Sehingga secara keseluruhan mengakibatkan gaya total drag yang diterima pelat datar dengan bump persegi panjang lebih besar daripada pelat datar dengan bump setengah lingkaran. Dari tabel 4.2 juga diketahui bahwa harga koefisien total drag $\left(C_{D}\right)$ bump persegi panjang lebih kecil daripada bump segitiga, hal ini dikarenakan aliran yang melewati bump segitiga lebih terseparasi daripada aliran yang melewati bump persegi panjang sehingga penurunan momentum dan tekanan statis aliran yang me lewati bump segitiga lebih besar daripada aliran yang me lewati bump persegi panjang. Sehingga secara keseluruhan mengakibatkan gaya total drag yang diterima pelat datar dengan bump segitiga lebih besar daripada pelat datar dengan bump persegi panjang. 


\section{PENUTUP}

\section{Simpulan}

Dari analisa hasil pengujian aliran melintasi pelat datar dengan bump berbentuk segitiga dengan kecepatan freestream $9.75 \mathrm{~m} / \mathrm{s}$ dan $15.5 \mathrm{~m} / \mathrm{s}$ dapat diambil beberapa kesimpulan sebagai berikut :

1. Separasi massive pada bump setengah lingkaran terjadi akibat momentum aliran tidak mampu mengatasi advarse pressure gradient dan tegangan geser antara permukaan bump dengan aliran fluida, sehingga untuk harga Re yang lebih besar akan mengakibatkan letak titik separasi lebih tertunda. Sedangkan pada bump segitiga dan bump persegi panjang separasi massive terjadi karena advarse pressure gradient yang tajam akibat perubahan sudut yang tajam permukaan bump, sehingga letak titik separasi massive tidak dipengaruhi oleh harga Re.

2. Semakin tegak lurus permukaan upstream bump dengan arah aliran maka mengakibatkan semakin besar gaya drag yang diterima oleh bump tersebut. Sehingga pressure drag untuk bump persegi panjang adalah yang terbesar, kemudian bump segitiga dan yang terkecil pada bump setengah lingkaran.

\section{DAFTAR PUSTAKA}

[1]. Andi Joko, 2001, "Studi Eksperimental Pengaruh Lokasi Permukaan Kasar Sebagai Inlet Disturbance Terhadap Karakteristik Boundary Layer Dan Gejala Separasi Pada Pelat Lengkung", Laporan Tugas Akhir, Jurusan Teknik Mesin FTI - ITS.

[2]. Ari Susanto, 2004, “Experimental Study of Turbulent Boundary Layer Characteristic Around a Singgle Transverse "V" Groove on the Flat Plate", Laporan Tugas Akhir, Jurusan Teknik Mesin FTI - ITS.

[3]. Bard Venas and Lars R. Saetran, 1999, Space-Time Correlations in Separated Flow Behind a Surface Mounted Obstacle, Department of Mechanics, Thermo and Fluid Dynamics Norwegian University of Science and Technology N-7034 Trondheim, Norway.

[4]. Fatchan Nurul, 2000, "Studi Eksperimental Pengaruh Inlet Disturbance Terhadap Karakteristik Boundary Layer Dan Gejala Separasi Pada Pelat Lengkung”, Laporan Tugas Akhir, Jurusan Teknik Mesin FTI - ITS.

[5]. Fox, Robert W. and McDonald, Alan T, 1994, Introduction to Fluid Mechanics, $4^{\text {th }}$ edition, John Wiley and Son, Inc.

[6]. M. Nuch, 2004, "Studi Eksperimental Karakte ris tik Turbulent Boundary Layer setelah Single Square Groove pada palat datar", Laporan Tugas Akhir, Jurusan Teknik Mesin FTI - ITS. 